\title{
A five-year analysis of patients with hemoptysis admitted to the clinic of the pulmonary disease of Cumhuriyet University Hospital
}

\section{CÜTF Göğüs hastalıkları kliniğine başvuran hemoptizi semptomlu hastaların beş yıllık analizi}

Güllhan Koşucu ${ }^{1}$, Sefa Levent Özşahiin², Ömer Tamer Doğan² ${ }^{2}$ Neslihan Taş³

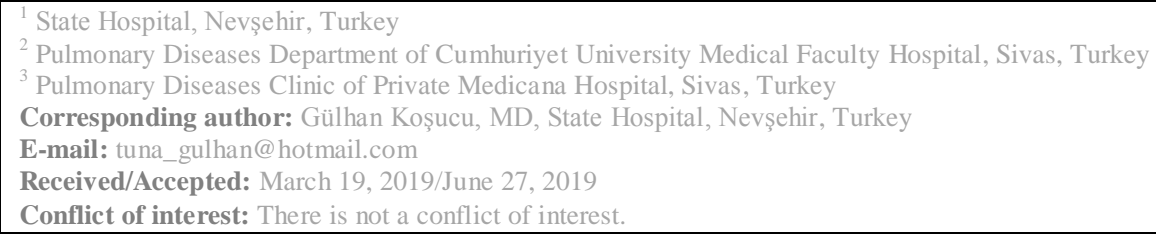

\section{SUMMARY}

This study aimed to identify the most common causes of hemoptysis and the methods utilized for the diagnosis, to determine the relationship between the etiological factors and the amount of hemoptysis, to establish the association between exposures and hemoptysis, and to reveal other possible factors related to hemoptysis in patients admitted to our clinic due to hemoptysis between January 2005 and December 2009. Thus, 385 cases were evaluated retrospectively. The most common causes of hemoptysis in the whole study population were identified as pneumonia, lung cancer and, pulmonary thromboembolism (33\%, 14.8 and $14.0 \%$, respectively). A stepwise approach including clinical and laboratory techniques, radiological methods, fiberoptic bronchoscopy, and echocardiograpy enhances the diagnosis of hemoptysis.

Keywords: Etiology, hemoptysis, lung cancer, pneumonia

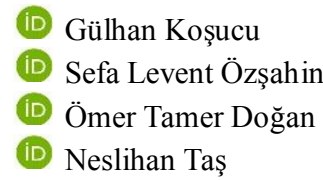

ORCID IDs of the authors: G.K. 0000-0003-2881-9360 S.L.Ö.0000-0001-6014-4696 Ö.T.D.0000-0002-4527-7754 N.T. $0000-0002-8905-1896$

\section{ÖZET}

Ocak 2005- Aralık 2009 tarihleri arasında servisimizde yatarak tedavi gören hemoptizi semptomu olan hastalarda; en sık hemoptizi sebeplerini saptamak, maruziyetler ve hemoptizi arasındaki ilişkiyi saptamak, hemoptizi ile ilișkili olabilecek diğer faktörleri saptamaktı. Hastanemize yukarıdaki tarihler arasında hemoptizi nedeniyle başvuran 385 olgu retrospektif olarak değerlendirildi. Tüm hasta grubunda en sik hemoptizi nedenleri \%33 pnömoni, \%14.8 akciğer kanseri ve \%14 pulmoner tromboemboli olarak tespit edildi. Sonuçta, hemoptizili hastalarda klinik ve laboratuar yöntemleri, radyolojik yöntemler, FOB, EKO gibi tetkikler basamaklar halinde kullanıldığında tanıya ulaşma olasılığı artmaktadir.

Anahtar sözcükler: Hemoptizi, etiyoloji, pnömoni, akciğer kanseri 


\section{INTRODUCTION}

Hemoptysis is bloody sputum or the spitting of blood, originating from the tissues below the larynx. Hemoptysis may be caused by the pulmonary parenchyma or tracheobronchial tree ${ }^{1}$. Tuberculosis and lung cancer are reported as the most common causes in the studies carried out in Turkey ${ }^{2}$. Posteroanterior (PA) chest radiography, computed tomography (CT), and bronchoscopy are the most frequently used diagnostic tests, but there is no consensus on which one will be used under which circumstances ${ }^{3}$.

\section{MATERIAL AND METHODS}

This research is a retrospective, cohort-type analytical study. For this study, permission was obtained from Cumhuriyet University Faculty of Medicine Ethics Committee Chairmanship with the decision numbered 2009-12/1.

The study included 385 patients with hemoptysis who were hospitalized in the Chest Diseases Clinic of Cumhuriyet University, Faculty of Medicine Hospital between January 2005 and December 2009.

\section{RESULTS}

Of the 385 patients included in the study, 130 (33.8\%) were female, and $255(66.2 \%)$ were male. The mean age of the patients was $56.8 \pm$ 16.7 years. There was no difference between the mean age of females and males $(57.4 \pm 16.9$ and
$56.6 \pm 16.7$ years, respectively). $71(18.4 \%)$ of the patients were under the age of 40 years. Information on biomass exposure of a total of 378 patients was reached; while 204 (54\%) patients had biomass exposure, $174(46 \%)$ patients had no biomass exposure. In 245 (64.8\%) out of the 378 patients whose asbestos exposure information was reached, there was asbestos exposure. In 210 patients who were smoking, the average use of cigarettes was detected to be $33.6 \pm 22$ pack-year. In our patients diagnosed with lung cancer, the rate of smoking was $84.2 \%$ with 48 patients, and all patients with a history of smoking were male patients. While among patients with lung cancer, four males $(7 \%)$ and four females $(7 \%)$ had no history of smoking, the smoking anamnesis of one patient could not be reached.

In patients with recurrent hemoptysis, the most common cause was lung cancer, with 16 (25.3\%) patients, and the second most common cause was pneumonia with $11(14.7 \%)$ patients. The most common lung cancer cell type causing recurrent hemoptysis was detected to be squamous cell type with 9 (15.9\%) patients.

The diagnostic distribution of hemoptysis, according to its characteristics, is presented in Table 1. Apart from the table, one patient had a heart valve replacement, and two patients had metastatic lung cancer as a cause of massive hemoptysis. In one patient, the cause of massive hemoptysis was not determined.

Table 1: Distribution of Diagnosis According to Hemoptysis Characteristics

\begin{tabular}{|l|c|c|c|c|}
\hline Diagnosis & $\begin{array}{c}\text { Mild } \\
\mathbf{n}(\boldsymbol{\%})\end{array}$ & $\begin{array}{c}\text { Moderate } \\
\mathbf{n}(\boldsymbol{\%})\end{array}$ & $\begin{array}{c}\text { Severe } \\
\mathbf{n}(\boldsymbol{\%})\end{array}$ & $\begin{array}{c}\text { Massive } \\
\mathbf{n}(\boldsymbol{\%})\end{array}$ \\
\hline Pneumonia & $93(36.8)$ & $21(35.6)$ & $12(19)$ & - \\
\hline Lung cancer & $37(14.6)$ & $8(13.6)$ & $11(17.5)$ & $1(12.5)$ \\
\hline PTE & $37(17)$ & $8(11.7)$ & $2(3.2)$ & $1(12.5)$ \\
\hline COPD & $20(7.9)$ & $2(3.4)$ & $3(4.8)$ & - \\
\hline Active TB & $13(5.1)$ & $2(3.4)$ & $3(4.8)$ & - \\
\hline Sequelae TB & $9(3.6)$ & $5(8.5)$ & $6(9.5)$ & - \\
\hline Bronchiectasis & $9(3.6)$ & $4(6.8)$ & $6(9.5)$ & $2(25)$ \\
\hline Total & $231(88.6)$ & $50(83)$ & $43(68.3)$ & $4(50)$ \\
\hline $\begin{array}{l}\text { PTE; pulmonary thromboembolism, COPD; chronic obstructive pulmonary disease, } \\
\text { TB; tuberculosis. }\end{array}$
\end{tabular}


The most common cause of hemoptysis was pneumonia with 127 (33\%) patients. Lung cancer was the second most common cause with 57 $(14.8 \%)$ patients, and squamous cell carcinoma type caused hemoptysis most frequently with 19 (33.3\%) patients. Behcet's disease was detected in 6 patients $(1.6 \%)$, hydatid cyst in 3 patients $(0.8 \%)$, and fungus ball in 4 patients $(1 \%)$ as the cause of hemoptysis. The hemoptysis cause of 9 (2.3\%) patients could not be determined (idiopathic). Seven patients with idiopathic hemoptysis were under 40 years of age, four patients did not smoke, and the anamnesis of one patient could not be reached.

\section{DISCUSSION}

Çelik et al. ${ }^{4}$ reported in their study that the mean age of patients with hemoptysis was 57 years (1987 years), $82 \%$ of the patients were male, and $63 \%$ of the patients were over 40 years of age. In another study, $89.2 \%$ of the 203 patients followed up with hemoptysis were male, and the mean age was 45.5 years ${ }^{5}$. In the study carried out by Doğan et al. ${ }^{6}$, the mean age of patients with hemoptysis symptoms was $53 \pm 12$ years, $73 \%$ of the patients were male, and the rate of patients aged over 40 years was $80 \%$. $33.8 \%$ of our 385 patients in total were female, and $66.2 \%$ were male. The mean age of our patients was $56.8 \pm$ 16.7 years. We determined the number of patients over the age of 40 years as $314(81.6 \%)$.

Koca et al. ${ }^{7}$ reported the rate of smoking as $97.5 \%$ and the average pack year as 36.3 in patients with hemoptysis. In another study, 61 patients with hemoptysis were evaluated, and the smoking rate was found to be $65.6 \%^{8}$. In our study, $95 \%$ of the 210 patients with a history of smoking were male. The average pack year of the smokers was detected to be $33.6 \pm 22$. In general, the smoking anamnesis of our patients displays similarities with other studies ${ }^{2,7,9}$. The rate of smoking was determined to be $84.2 \%$ in our patients with lung cancer, and this finding was consistent with the literature ${ }^{10,11}$.

Except for smoking, biomass, and asbestos exposure information of our patients was evaluated. $102(78.5 \%)$ female and $102(40 \%)$ male patients who were exposed to biomass, and $74(56.5 \%)$ female and $171(69 \%)$ male patients who were exposed to asbestos were detected. In the literature, information which evaluates the relationship between biomass and asbestos exposure and hemoptysis could not be reached, but a high rate of exposure was observed in our patient population. Especially in patients with COPD and lung cancer, these exposures may be effective in the emergence of the current disease, rather than being related to hemoptysis ${ }^{12,13,14}$.

Arslan et al. ${ }^{15}$ determined mostly mild to moderate bleeding in patients with hemoptysis, and they also found lung cancer as the most common cause in recurrent and first attack hemoptysis. In the study, mostly mild hemoptysis was detected in lung cancer. There are studies which found a significant relationship between lung cancer and mild hemoptysis ${ }^{4,16,17}$. In the study by Fidan et al. ${ }^{18}$, recurrent hemoptysis was most commonly determined in patients with bronchiectasis. In another study, 29.3\% recurrent hemoptysis and $74.9 \%$ mild hemoptysis were observed, and mild hemoptysis was most frequently associated with lung cancer ${ }^{7}$. Another study carried out with 143 cases with hemoptysis symptoms reported that the rate of recurrent hemoptysis was $23.1 \%$ and the associated disease was bronchiectasis, and the rate of mild hemoptysis was $67.8 \%$ and the associated disease was lung cancer ${ }^{2}$. In our study, the rate of recurrent hemoptysis was $19.5 \%$, and the disease associated with recurrent hemoptysis was lung cancer in the first place and pneumonia in the second place, which was consistent with the literature. In our study, mild hemoptysis was determined to be $65.7 \%$. The most common disease associated with mild hemoptysis was determined as pneumonia in contrast to the literature. In our study, lung cancer and bronchiectasis, which were reported to be the most frequently associated diseases with mild hemoptysis in the related literature were in the second and seventh places, respectively. In our patients with lung cancer, mild hemoptysis was observed most frequently at the rate of $14.6 \%$, in accordance with the literature.

In our study, the rate of moderate hemoptysis was found as $15 \%$, of severe hemoptysis as $16.4 \%$ and of massive hemoptysis at $2.1 \%$. The disease, which is the most common cause of moderate hemoptysis, was pneumonia, the most common cause of severe hemoptysis was again pneumonia, and the most common cause of massive hemoptysis was bronchiectasis. In our study, the amount of hemoptysis and the ratio of the most frequently associated disease were not consistent with the literature 2,7,14. This inconsistency was thought to be related to characteristics of the patient population, the geographical region, the hospital where the study was conducted, the number of patients included in the study, and differences in the time frame.

Sevim et al. ${ }^{19}$ reported hemoptysis at a rate of 
$32 \%$ in patients with pulmonary thromboembolism. In our study, we detected 54 (14\%) PTE patients who had hemoptysis symptoms, and PTE was the third most common cause of hemoptysis.

When the results of nine studies which were carried out between 1941 and 2000 and which investigated the causes of hemoptysis were evaluated, the most important cause of hemoptysis was lung cancer with a rate of $42.3 \%$, followed by bronchiectasis with $17.4 \%$ and bronchitis with $15.7 \%$. Although the tuberculosis rate varies considerably by regions, it is observed to decrease gradually over the years ${ }^{17}$. In our study, pneumonia was detected as the most common cause of hemoptysis at a rate of $33 \%$. Pneumonia was followed by lung cancer with $14.8 \%$, and pulmonary thromboembolism with $14 \%$. Koca et al. (7) reported in their study that the first three most common causes of hemoptysis were lung cancer with $28.4 \%$, active pulmonary tuberculosis with $16.4 \%$, and pneumonia with $16.1 \%$. In some studies, $4,6,14,17$, lung cancer was reported as the most common cause of hemoptysis at the rates of $38.2 \%, 48 \%$, $34 \%$, and $34 \%$, respectively. In our study, in contrast to the literature, pneumonia was the most common cause of hemoptysis, but the inconsistency with the literature, lung cancer was among the first three causes. Furthermore, pneumonia has also been frequently reported among the first three causes in the studies ${ }^{7,14}$.

Koca et al. ${ }^{7}$ reported that the type of lung cancer causing hemoptysis most commonly was squamous cell carcinoma. In our study, squamous cell carcinoma was determined as the type of lung cancer, causing hemoptysis most commonly with 19 (33.3\%) patients.

In the study by Fidan et al. ${ }^{17}$, bronchiectasis was reported at a high rate of $25 \%$. In some studies ${ }^{14,15,20}$, bronchiectasis has been reported at low rates such as $1 \%$ (the first two studies) and $6.4 \%$. In the present study, the rate of bronchiectasis was determined as $5.5 \%$. In a study conducted in Japan on 80 hemoptysis patients, the most common causes were determined as bronchitis (26.7\%), bronchiectasis (19\%), and infection $(14 \%)^{21}$. Based on this, it is possible to say that bronchiectasis is still an essential problem in developed countries as well as in developing countries like Turkey.

\section{CONCLUSION}

Hemoptysis is a significant symptom that may occur as a result of various etiological factors.
The demographic characteristics, such as age and gender of patients with hemoptysis, vary in various studies. This situation was thought to be related to the patient population, time frame, hospital where the research was conducted, and the number of patients.

In our study, pneumonia was detected as the most common cause of hemoptysis. Lung cancer and PTE were determined as the second and third causes, respectively. In the retrospective studies of the 1940s and 50s, tuberculosis and bronchiectasis were the more common causes of hemoptysis, whereas studies conducted in recent years have reported an increase in carcinoma cases and a decrease in tuberculosis and bronchiectasis cases ${ }^{22}$.

In our study, tuberculosis and bronchiectasis were not among the first three causes. This result may be attributed to the effective use of antituberculosis and nonspecific antibiotic therapy in recent years.

In the present study, inconsistent with the literature, lung cancer was determined as the most common cause of recurrent hemoptysis. While mild hemoptysis was most commonly associated with lung cancer, it was detected most frequently in pneumonia patients in our study. This case may be due to the high number of patients diagnosed with pneumonia.

In the presence of idiopathic hemoptysis, close follow-up is required in terms of malignancy, especially when patients are over 40 years of age and smoke.

As a result, the symptoms of hemoptysis should be taken seriously by every physician, and further examination should be performed if it is required.

\section{REFERENCES}

1. Depalo VA, Mccool D. Evaluation of the patient with pulmonary disease. The History \& Physical Examination in Pulmonary Medicine. In: Hanley M, Welsh C, Diagnosis $\&$ Treatment in pulmonary medicine. New York: Lange Medical Books/McGraw Hill;16-25, 2003.

2. Ünsal E, Köksal D, Çimen F, Hoca NT, Şipit $\mathrm{T}$. Analysis of patients with hemoptysis in a reference hospital for chest diseases. Tüberküloz ve Toraks Dergisi;54(1):34-42, 2006.

3. McGuinness G, Beacher JR, Harkin TJ, Garay SM, Rom WN, Naidich DP. Hemoptysis: prospective high- resolution CT/ 
bronchoscopic correlation. Chest; 105: 1155 62, 1994.

4. Çelik $P$, Gönlügür $U$, Akın $M$, Orman A. Hemoptizili

Olgularımızın Analizi [Analysis of Cases with Hemoptysis]. Heybeliada Tıp Bülteni; 3: 45-8, 1997.

5. Özgül MA, Turna A, Yıldız P, Ertan E, Kahraman S, Yilmaz V. Risk factors and recurrence patterns in 203 patients with hemoptysis. Tüberküloz ve Toraks Dergisi; 54: 243-8, 2006.

6. Doğan ÖT, Berk S,Engin A, Akkurt İ. Hemoptizide etyolojik faktörler [Etiological factors in hemoptysis]. Cumhuriyet Tip Dergisi;32: 48-53, 2010.

7. Koca H, Özden ŞS, Güldaval F, Özacar R. Hemoptizi: $\quad 311 \quad$ Olguluk bir Retrospektif Analiz

[Hemoptysis: A Retrospective Analysis of 311 Cases]. İzmir Göğüs Hastanesi Dergisi; 22(3): 65- 6, 2008.

8. Ataç G, Erdem İ, Saraç S, Öztaş S, Köklü S, Tümer Ö, Kurutepe M. Gögüs Hastalıklanı Referans Hastanesindeki 61 Hemoptizili Hastanın Retrospektif İncelenmesi [Retrospective Examination of 61 Patients with Hemoptysis in a Reference Hospital for Chest Diseases]. Haydarpaşa Numune Eğitim ve Araştırma Hastanesi Tip Dergisi; 48(3):165-170, 2008.

9. Arslan S, Çimen P, Tekgül S, Güren E, Yalnız E, Özden EP. Hemoptizili olgularda etiyoloji ve akciğer grafisi, bilgisayarlı tomografi (BT), fiberoptik bronkoskopi (FOB) bulgularının değerlendirilmesi [Evaluation of etiology and results of chest x-ray, computed tomography (CT), and fiberoptic bronchoscopy (FOB) in cases with hemoptysis]. İzmir Göğüs Hastanesi Dergisi;19(3): 93-100, 2005.

10. Pisters K, Ginsberg R, Giroux D, Kris M, Putnam JB, Roberts JR et al. Bimodality lung oncology team (BLOT) trial of induction paclitaxel/carboplatin in early stage non-small cell lung cancer (NSCLC): Long term followup of a phase II trial. Proc Am Soc Clin Oncol 22: 633 (abstract 2544), 2003.

11. Field JK. Selection and validation of new lung cancer markers for the molecular pathological assessment of individuals with a high risk of developing lung cancer. In: Brambilla C,
Brambilla E. (Editors). Lung tumors fundamental biology and clinical management. New York: Marcel Dekker Inc: 287-302, 1999.

12. Global Initiative For Chronic Obstructive Lung Disease. Global Strategy For The Diagnosis, management, And Prevention Of Chronic Obstructive Pulmonary Disease (GOLD). Update 2006.

13. Behera D, Balamugesh T. Indoor air pollution as a risk factor for lung cancer in women. $\mathbf{J}$ Assoc Physicians India; 53: 190-2, 2005

14. Gani H, Seyfkli Z, Çelik VK, Akkurt İ. Abadoğlu Ö. Kırsal alanlardaki kadınlarda biomass maruziyetinin lipid peroksidasyon ve antioksidan enzim aktivitelerine etkileri [Effects of biomass exposure on lipid peroxidation and antioxidant enzyme activities in women in rural areas]. Toraks Dergisi; 1:13-18, 2000.

15. Arslan S, Çimen P, Tekgül S, Güren E, Yalnız E, Özden EP. Hemoptizili olgularda etiyoloji ve akciğer grafisi, bilgisayarlı tomografi (BT), fiberoptik bronkoskopi (FOB) bulgularının değerlendirilmesi [Evaluation of etiology and results of chest x-ray, computed tomography (CT), and fiberoptic bronchoscopy (FOB) in cases with hemoptysis]. İzmir Gögüs Hastanesi Dergisi;19(3): 93- 100, 2005.

16. Johnston H, Reisz G. Chancing spectrum of hemoptysis: underlying causes in 148 patients undergoing diagnostic fiberoptic bronchoscopy. Arch Intern Med; 149:1661-8, 1989

17. Yavaşoğlu G, Karalar S, Balcıŏlu İ. Hemoptizili olguların retrospektif değerlendirilmesi [Retrospective evaluation of cases with hemoptysis]. TUSAD XXIII. Kongre Kitab1; 20: 583-6, 1996.

18. Fidan A, Özdoğan S, Oruç O, Salepçi B, Öcal Z, Çağlayan B. Hemoptysis: a retrospective analysis of 108 cases. Respir Med; 96:67780, 2002.

19. Sevim T, Ataç G, Ongen A, Özmen İ, Kapaklı N, Horzum $G$ et al. Yirmibeş polmoner emboli olgusunun değerlendirilmesi [Evaluation of twentyfive cases of pulmonary embolism]. Solunum Hastalıklar1; 12: 39-43, 2001.

20. Santiago S, Tobias J, William AJ. A reappraisal of the causes of hemoptysis. Arch Intern Med; 151: 2449-51, 1991. 
21. Seki N, Shiozaki G, Ota M. Risk factors for a second episode of hemoptysis. Clinical Medicine Insights: Circulatory Respiratory and Pulmonary Medicine; 3:1-7, 2009.

22. Hirshberg B, Biran I, Glazer M, Kramer MR. Hemoptysis: Etiology, evaluation, and outcome in a tertiary referral hospital. Chest; 112:440- 444, 1997. 